\title{
Vocabulaire Technique International de l'Ingénieur
}

\author{
The Engineer's Technical and International Vocabulary \\ avec le concours de M. G. RANSFord et du Professeur GIROUd
}

\section{A PROPOS DE “ WATERSHED"}

La correspondance que nous recevons à propos de notre Vocabulaire Technique est la meilleure preuve de l'attention avec laquelle cette rubrique est suivie pas nos lecteurs. Il nous serait, évidemment, tout à fait impossible de présenter toutes les remarques de détail qui nous parviennent. Cependant, la lettre que nous reproduisons ci-dessous nous semble particulièrement intéressante: d'abord elle précise fort judicieusement certaines nuances du sens de l'un des termes récemment analysés dans nos colonnes; mais de plus, elle souleve indirectement un problème d'ordre général sur lequel nous nous devons de prendre position. Voici donc la lettre de M. Teardale :

Je regrette de voir la Houille Blanche, avec son numéro 1 de 1953, entériner dans son Vocabulaire International de l'Ingénieur une erreur d'interprétation d'un mot anglais, erreur qui malheureusement a gagné du terrain au cours de ces dernières années.

"Watershed» désigne la ligne de crête séparant un bassin versant d'un autre bassin versant, mais non le bassin versant lui-même. Cette ligne de crête (Watershed) répand l'ean tombant en pluie sur ses deux versants dans des directions opposées. En termes généraux, la chaine Penine, en Angleterre, est un «Watershed $\gg$, une ligne de partage des eaux à grande échelle. De deux gouttes de pluie tombant a 1 ou 2 métres l'une de l'autre a Peak District, par exemple, l'une se dirigera vers la mer d'Irlande, tandis que l'antre gagnera la mer du Nord.

"Watershed》 désigne la disposition du relief provoquant cette divergence des routes empruntées par les deux gouttes d'eau. Par contre le bassin de la Trent, rivière qui véhiculera la

\section{"WATERSHED "}

The correspondence which we receive in connection with our Technical Vocabulary is the best proof of the interest with which this section is followed by our readers. It is obviously impossible for us to publish all the comments which reach us. However, the letter which we reproduce below seems to us to be particularly interesting; primarily, it discusses in a most discerning manner certain shades in meaning of a term recently analysed in our columns; but, in addition, it indirectly raises a general problem on which we must state our point of view.

Here, then, is the letter from Mr. Teardale:

I regret to see, in No. 1 (8th Year) of la Houlle Blanche for January-February 1953, authority given in your International Technical Vocabulary, to an error in the application of an English word which has unfortunately been gaining ground during the last few years.

A "watershed" is a dividing ridge which separates one drainage or catchment area from another: it is not a catchment area or collecting basin. The watershed sheds the water falling as rain down its two slopes in opposite directions. In broad terms, The Penine Range of England is a watershed on a large scale. Of two rain drops, falling within a yard or two of each other in, say, the Peak District, one may eventually find its way into the Irish Sea, while the other goes to the North Sea.

The "watershed" is the configuration of the ground which causes' the divergence in the courses taken by the two drops of water. On the other hand, the basin of the River Trent, down which the eastbound drop may travel to 
goutte Est pour rejoindre la Humber puis la mer du Nord, constitue un catchment area (bassin versant) et non un watershed.

J'espère que vous pourrez publier à ce sujet une mise au point permettant de préserver la pureté de la langue anglaise, el je vous prie de croire...

Sur le fond, notre correspondant a incontestablement raison. Si l'on tient compte de son étymologie, «watershed » est bien la ligne de partage des eaux, alors que « catchment area», "drainage area», "catchment basin», "drainage basin» désignent spécifiquement le «bas$\sin$ versant $\gg$.

Malheureusement, en technique comme ailleurs, le Vocabulaire n'est pas un ensemble figé dans le temps: les mots vivent, leur sens évolue, se transforme, se métamorphose parfois, et il arrive un moment où, bon gré mal gré, il convient d'admettre les nouveaux usages.

Or le fait est - comme notre correspondant le remarque lui-même - que, de plus en plus, «watershed» est employé dans le sens de bassin versant. Des dictionnaires pourtant prudents, comme celui de Webster ou celui de Funk et Wagnall mentionnent cette signification en second lieu; bien mieux le Vocabulaire intitulé : «Letter symbols and Glossary for Hydraulics,- ASCE Manuals of Engineering Practice $n$ " $11 \gg$ indique comme premier sens de Watershed celui de bassin versant.

Enfin, il suffit de lire la littérature de langue anglaise, américaine en particulier (par exemple les Transactions of the American Geophysical Union) pour constater que cet emploi du mot Watershed est, peut-être à tort, extrêmement répandu et très généralement admis.

Dès lors et tout en insistant sur l'intérêt et la valeur de la remarque de notre correspondant, il nous est impossible de ne pas tenir compte des faits et de ne pas signaler cet emploi tout à fait courant de watershed. Nous avons eu tort seulement de ne pas rappeler le sens étymologique et toujours admis de ce terme.

Il est bien évident que notre Vocabulaire Technique International n'est pas destiné à juger, à critiquer ou à justifier l'usage de tel ou tel terme. Notre ambition est beaucoup plus modeste, et nous nous estimons très satisfait lorsque nous sommes parvenus à rassembler, à classer et à présenter des termes consacrés à tort ou à raison - par l'usage.

Nous reprendrons naturellement, dans un prochain numéro, la publication de l'étude de MM. Ransford et Ginoud sur les verbes signifiant: mouiller, couler ou déverser. the Humber and the North Sea, is not a watershed, but a catchment area.

I hope that you will publish a correction, in the interests of preserving the well of English undefiled, and remain, Sir,...

Basically, our correspondent is undeniably right. If one agrees with his etymology, "watershed" is certainly a line dividing water; it is not a catchment area.

Unfortunately, in technique as otherwise, vocabulary is never stationary: words live, and sometimes undergo an evolution, a transformation or metamorphosis of meaning, and the moment arrives when, whether we like it or not, they are adapted to new definitions.

Now the fact is-as our correspondent points out himself-that "watershed" is used, more and more, in the sense of a catchment area. Dictionaries such as "Webster" or "Funk and Wagnall" mention this as a secondary meaning; furthermore, the "Letter symbols and glossary for Hydraulics-ASCE Manuals of Engineering Practice $n^{\circ} 11$ "gives a first definition of "watershed" as "catchment area".

It is only necessary to read English language, and in particular American literature (The Transactions of the American Geophysical Union, for example) to ascertain that this use of the word watershed is, perhaps wrongly, extremely well-know and very widely used.

While reitaring the value and interest of our correspondent's remarks, it is impossible for us to both ignore facts and fail to point out his completely current use of the word "watershed". We have erred only in failing to recall the etymological and generally accepted meaning of this expression.

It is obvious that our International Technical Vocabulary is not designed to judge, criticize or justify the usage of any terms. Our ambition is more modest, and we are satisfied if we manage to collect, classify and publish terms established-rightly or wrongly-by common use.

We will, of course, continue in a latter issue publication of Mrs. RansFord and GrRoun's investigations of the verbs: wet, flow, pour. 